\title{
Ayurveda: The Intangible Cultural Heritage of India
}

\author{
Vijay Kumar Srivastava', Anubha Srivastava ${ }^{2}$
}

${ }^{1}$ Ayurveda Practitioner (On deputation), Traditional and Complementry Medicine Division, Ministry of Health, Malaysia.

${ }^{2}$ Assistant Professor, Department of Rachana Sharir, Government Ayurveda PG College and Hospital, SSU, Varanasi.

DOI: https://doi.org/10.24321/2394.6547.201809

\begin{abstract}
Publication and documentation are the most essential thing for Vedic literature to protect them from Piracy. The term Vedic literature means the four Vedas, their Samhita and the allied literature based on or derived from the Vedas. The four Vedas are Rigveda, Samaveda, Yajurveda and Atharvaveda including their Samhitas and Brahmanas attached to each Samhita7. The current scenario is changing globally, any knowledge related to science and technology is regulated under Patent and copy right act and laws. For getting a patent the claimed thing should have the following 3 qualities; it should be new, novel (nonobvious) \& have commercial application. The Vedic literatures are spared from patent regulation act, because this knowledge is in public domain and comes to instance since thousands of years; before the creation of patent laws.
\end{abstract}

Keywords: Ayurveda, Bio-piracy, Copy right, Haldi, Intangible, Neem Basmati, Patent

\section{Introduction}

The social, cultural and historical customs of a country are their own property and it is their right to save them from misappropriation. The term widely accepted for defining the concept of living heritage, as different from built and "material" aspects, is 'intangible cultural heritage', a term wide-ranging to include aspects such as folklore, traditional knowledge, oral expressions, literary and artistic expressions, languages and several other forms of experience and knowledge. ${ }^{2}$ According to Acharya Charak, the knowledge can meet to us from 4 ways known as Pramanas (Declarations). ${ }^{3}$ These are Aptopdesh (Written testimonial), Pratyaksha (Direct observation), Anumana (Indirect observation based on previous experience) and Yukti (Indirect observation by correlation of things). First and foremost is Aptopdesh (the written testimonial); which is the immense resource of knowledge; is retrievable and is an open resource for misuse.

We are lucky enough that we have the oldest medical literature available in the world i.e. Ayurveda. So, we have to concentrate on our issues and must explore the hidden facts of Ayurveda and other Vedic literatures on scientific parameters. There are so many examples in our classics which were a matter of wonder in the past but are common in practice now days. A few examples are 'Test tube baby like births of Kauravas in Mahabharata from Kalash, ${ }^{4}$ Pushpak viman (Aero plane) was used for travelling by Ravana during Ramayan period, ${ }^{5}$ different Yogic postures proved their therapeutic utilities, several Ayurveda principles and medicines have verified to be useful for mankind. Neem, Haldi, Baasmati rice, Aloe-vera etc. are a few examples which are well described in our Ayurveda classics but got patented by other countries, due to lack of their proper documentation. Similarly, so many patents have been granted by USPTO (United states patent and trade mark office) and EPO (European patent office), with the invention of some chairs which can fold according to the Yoga mudra desired. ${ }^{6}$

Traditional Knowledge Digital Library (TKDL) integrates widely scattered and distributed references on the

Corresponding Author: Dr. Vijay Kumar Srivastava, Traditional and Complementry Medicine Division, Ministry of Health, Malaysia

E-mail Id: srivast_25@yahoo.com

Orcid Id: https://orcid.org/0000-0003-3233-2889

How to cite this article: Srivastava VK, Srivastava A. Ayurveda: The Intangible Cultural Heritage of India. J Adv Res Ayur Yoga Unani Sidd Homeo 2018; 5(2): 14-17. 
traditional knowledge systems, (Ayurveda, Yoga, Unani, Siddha, Vastu etc.) of India in a retrievable form. TKDL acts as a bridge between the traditional and modern knowledge systems, a bridge between the knowledge contained in an old Sanskrit shloka (verse) and the computer screen of a patent examiner, thus breaks the format and language barrier of the prior art, available in authoritative texts of Ayurveda (in Hindi and Sanskrit). TKDL is not a prior art. "A patent is a statutory grant of certain monopoly rights by the Government to the grantee for his invention". This grant is for a defined period and subject to certain conditions.

\section{Various Methods to Prevent Piracy}

Publication and documentation of Vedic literature is the most essential thing for their protection from Piracy. Knowledge related to art, science and technology is regulated under Patent and copyright laws. Intellectual property is protected through these regulations. Government of India has designed a software to protect these intellectual properties. It is a property created by individual intelligence, hence personal. Intellectual property right and Indian patent act were established in $1970 . .^{7}$ Government of India give a specific Patent number; it is a kind of 20-year permission to that fellow to use that technology. For getting a copyright it must have some original concepts. For getting a Patent the thing should be New, Novel \& Non-obvious; further the patent is of two types the Product patent and the Process patent. Simply the Patent protects the Idea while Copyright protects the expression of the Idea. ${ }^{8}$ But the Vedic literatures are spared from patent regulation act because the knowledge is in public domain and Comes to instance since thousands of years; before the creation of patent laws.

\section{Patents}

As per Article 27 of TRIPS, an "Invention means a product or process in all field of technology, provided that they are new, involve an inventive step and capable of industrial application." Inventive step is normally understood as art which is non-obvious and does not have a part of prior art. A patent for an invention is the grant of a property right to the inventor. Patents are granted for new, useful and non-obvious inventions for a period of 20 years from the filing date of a patent application, and provide the right to exclude others from exploiting the invention during that period. ${ }^{8}$

\section{Copy right}

Copyright (or author's right) is a legal term used to describe the rights that creators have over their literary and artistic works. Works covered by copyright range from books, music, paintings, sculpture, and films, to computer programs, databases, advertisements, maps, and technical drawings. Copyright law aims to balance the interests of those who create content, with the public interest in having the widest possible access to that content. WIPO administers several international treaties in the area of copyright and related rights; but traditional knowledge cannot allow for a copy right as well. Indian copyright act was first implemented in 1957. Duration of copyright is lifetime of the author + sixty years from the beginning of the calendar year next following the year in which the author dies. ${ }^{8}$

\section{Bio-piracy of Traditional Knowledge}

The indigenous knowledge has always remained an easily accessible treasure and thus has been open to stealing. The indigenous knowledge particularly that on utilization of the traditional knowledge for the treatment of various diseases has provided the leads for development of biologically active molecules by the technology rich countries. In other words, traditional knowledge is being increasingly exploited for bio-prospecting. Traditional knowledge is misappropriated also because it is conveniently assumed that since it has been publicly disclosed and is available in open domain; communities have given up all claims over it. Traditional Knowledge includes both the codified (documented) as well as non-codified information (not documented but may be orally transmitted). ${ }^{6}$

Bio-piracy of codified traditional knowledge has been rampant in India for the reasons that there exists a language and format barrier since such information exists in Sanskrit or other regional languages, the patent offices are unable to use this information as prior art. However, this knowledge is easily accessible for misappropriation. Formulations used for the treatment of human ailments from traditional knowledge are time-tested since they have been in practice for centuries. The reliability of the traditional medicine systems coupled with the absence of such information with patent offices provides an easy opportunity for interlopers for getting patents on these therapeutic formulations derived from traditional medicine systems though there is no preventive step involved. ${ }^{6}$

\section{Traditional Knowledge Patents taken on Non- Patentable Innovation}

The grant of patents on non-patentable knowledge (linked to traditional medicines), which is either based on what is already a part of the traditional knowledge of the developing world, or a minor variation thereof, has been causing a great concern (emotive and economic) to the developing world. Some of the examples given ahead illustrate the bio-piracy of traditional knowledge and in many of these cases the country had to fight at considerable cost and effort to revoke the patents granted, which however, may not be possible for all the inappropriate patents taken on the traditional knowledge since it involves huge cost and efforts. Problem in TK piracy is a global issue not limited to few countries. 
It is also indicated by some of the illustrative examples in Indian Ayurvedic Systems where applicants have obtained patents at USPTO by translating the knowledge available in public domain in India. This knowledge contained in authoritative textbooks is normally available in Sanskrit/ Hindi. Normally these textbooks are not accessible to the patent examiner. Even if accessible a language barrier existed.

Translation under any criteria in IP system does not get recognized as novelty therefore all these patents and several such patents need be revoked/cancelled suo-moto by the offices who have inadvertently granted these patents.

\section{Protecting Codified Traditional Knowledge through Traditional Knowledge Digital Library (TKDL)}

Patent examiners in the international patent office's use available resources for searching the appropriate non-patent literature sources, when considering the patentability of any claimed subject matter. Patent literature, however, is usually wholly contained in several distinctive databases and can be more easily searched and retrieved, whereas non-patent literature prior art may be buried somewhere in the many and diverse sources. Therefore, there was a felt need to create more easily accessible non-patent literature databases that deal with traditional knowledge and make them amenable to search by the state of art internet search engines.

\section{Traditional Knowledge Resource Classification (TKRC)}

Traditional Knowledge documentation lacked a classification system. Therefore, a modern classification based on the structure of International Patent Classification (IPC) was evolved. This has been attempted for Ayurveda and has been named as Traditional Knowledge Resource Classification (TKRC). It was essential to seek international recognition to this innovative effort. Therefore, linkages were established with IPC Union at World Intellectual Property Organization (WIPO) Geneva. This is likely to have significant impact on the system of search and examination while granting patents in the area of traditional knowledge, whereby the possibilities of grant of wrong TK patents shall get significantly reduced. ${ }^{6}$

\section{Some Examples of Bio-piracy of Traditional Knowledge $^{6}$}

\section{Turmeric (Curcuma longa Linn.)}

The rhizomes of turmeric are used as a spice for flavoring in Indian cooking. It also has properties that make it an effective ingredient in medicines, cosmetics and as a color dye. As a medicine, it has been traditionally used for centuries to heal wounds and rashes.
In 1995, two expatriate Indians at the University of Mississippi Medical Centre were granted a US patent (no.5, 401,504) on use of turmeric in wound healing. The Council of Scientific \& Industrial Research (CSIR), New Delhi of India filed a re-examination case with the USPTO, challenging the patent on the grounds of prior art. CSIR argued that turmeric has been used for thousands of years for healing wounds and rashes and therefore its medicinal use was not a novel invention. Their claim was supported by documentary evidence of traditional knowledge, including ancient Sanskrit text and a paper published in 1953 in the Journal of the Indian Medical Association. Despite an appeal by the patent holders, the USPTO upheld the CSIR objections and cancelled the patent. The turmeric case was a landmark judgment case as it was for the first time that a patent based on the traditional knowledge of a developing country was successfully challenged. The US Patent and Trademark Office revoked this patent in 1997, after ascertaining that there was no novelty; the findings by innovators having been known in India for centuries.

\section{Neem (Azadirachta indica A. Juss.)}

Neem extracts can be used against hundreds of pests and fungal diseases that attack food crops; the oil extracted from its seeds can be used to cure cold and flu; and mixed in soap, it provides relief from malaria, skin diseases and even meningitis. In 1994, EPO granted a patent (EPO patent No. 436257) for a method for controlling fungi on plants with the help of hydrophobically extracted Neem oil. In 1995, a group of international NGOs and representatives of Indian farmers filed legal opposition against the patent. They submitted evidence that the fungicidal effect of extracts of Neem seeds had been known and used for centuries in Indian agriculture to protect crops, and thus was a prior art and unpatentable. In 1999 the EPO determined that according to the evidence all features of the present claim have been disclosed to the public prior to the patent application and the patent was not considered to involve an inventive step. The patent granted on Neem was revoked by the EPO in May 2000.

\section{Other examples}

To cite some more examples of bio-piracy, for the plant Phyllanthus amarus Schum.et Thonn, used for Ayurvedic treatment for jaundice, a US patent has been taken for use against Hepatitis B. The plant Piper nigrum Linn. is used for Ayurvedic treatment for vitiligo (a skin pigmentation disorder). A patent has been taken in UK for the application of a molecule from Piper nigrum Linn. for use in treatment of vitiligo.

The appropriation of elements of this collective knowledge of societies into proprietary knowledge for the commercial profit of a few is one of the concerns of the developing world. An urgent action is needed to protect these 
fragile knowledge systems through national policies and international understanding linked to IPR, while providing its development and proper use for the benefit of its holders. In February, 2002 twelve nations viz. China, Brazil, India, Indonesia, Costa Rica, Colombia, Ecuador, Kenya, Peru, Venezuela and South Africa which are rich in biodiversity signed an alliance to fight bio-piracy and press for rules protecting their people's rights to genetic resources found on their land.

\section{Conclusion}

The UNESCO Convention in 2003 on Intangible Cultural Heritage defines intangible cultural heritage as broad enough to include diverse experiences and expressions across the globe, as "the practices, representations, expressions, knowledge, skills as well as the instruments, objects, artefacts and cultural spaces associated with that communities, groups and, in some cases, individuals recognize as part of their cultural heritage". The major domains include oral traditions and expressions, including language; social practices, rituals and festive events; knowledge and practices concerning nature and the traditional craftsmanship. What western world achieve they disclose it with big banner, but despite of having so many intangible knowledge's, we not ever tell what we have. We always fight within, regarding the authenticity of the available data, and never try to confirm it or share it. And the most shocking is that we try to reserve the knowledge for self and family unit rather than to disperse it.

In recent years, patents for traditional knowledge-based inventions have been granted, and subsequently revoked, because the relevant traditional knowledge could not be accessed as prior art by the patent examiner when doing search for establishing novelty of invention claimed for patents. For example, grant of patents on Turmeric, Neem and Basmati Rice. The reason behind this non-access was that such information was not available, compiled and orderly arranged; there were no effective search tools for the retrieval of such information and there was no searchable database available to the patent granting authorities. Hence government of India is now working in this direction and tries to develop data base software to avoid this type of wrong patents and piracy. Traditional knowledge digital library (TKDL) is the name given to this software, in which each and every document written in the classics can be shown to patent office's worldwide. They have to see the literature contained in it before giving Patents, if the knowledge is already there in public domain, it will not be patented by any one. In initial phase only Ayurveda, Yoga, Siddha and Unani are under creation of TKDL but later on other traditional knowledge can be prevented and get safeguards from wrong patents with the help of their documentation. This is the only way; we can do for the uplifting of Vedic literature.

\section{Conflict of Interest: None}

\section{References}

1. www.gktoday.in.

2. Intangible cultural heritage: community participation and development. Department of Museology, Banaras Hindu University, Varanasi. 2015.

3. Charaka Samhita of Agnivesha elaborated by Charaka \& Drudhabala with Ayurveda Dipika Commentary by chakrapanidatta, edited by Vaidya Jadavaji Trikamji Acharya, Vimana sthana chapter 4,verse no.3, page no.247 Choukhambha Surbharati Prakashan Varanasi Reprinted 2005.

4. Badrinath, Chaturvedi. The Mahābhārata : An Inquiry in the Human Condition, New Delhi, Orient Longman (2006).

5. Arya, Ravi Prakash (ed.).Ramayana of Valmiki: Sanskrit Text and English Translation. (English translation according to M. N. Dutt, introduction by Dr. Ramashraya Sharma, 4-volume set) Parimal Publications: Delhi, 1998, ISBN 81-7110-156-9.

6. www.niscair.res.in.

7. www.ipindia.nic.in.

8. www.copyright.gov.in. 